\title{
Glossary of Arabic Words
}

\section{'Auyūn (sing. 'ayn): water sources or springs ${ }^{1}$}

Aqdīya (sing. qaḍā): administrative divisions of the provinces ruled by the Ottoman Empire ${ }^{2}$ Bey: Ottoman title given to some governors in the Ottoman Empire ${ }^{3}$

Eyālet: largest administrative divisions in the Ottoman Empire ${ }^{4}$

Fatwa: legal opinion or learned interpretation by a qualified jurist or mufti given on issues pertaining to Islamic law

Hāra: neighborhood.

al-Halfa (sparto or Cortaderia selloana): species of palms, grows in poor and very dry soil and very high temperatures in North Africa, among other places, leaves are thin (one-millimeter width) and can be one meter long, used in handicrafts like producing mats $^{6}$

Ḥașir (mats): made of the sparto (halfa), made manually or with looms and used domestically to sit on ${ }^{7}$

Henna: plant, which leaves are dried and used to dye hair, skin or fingernails as body art ${ }^{8}$ $a l-H i z b$ : political party.

Eid al-Aḍha: Islamic festival two months after the fasting month of Ramaḍān, celebrated after Haj $^{9}$

Eid al-Fițr: Islamic festival, celebrated immediately after the fasting month of Ramaḍān, there are special prayers at this festival that gathers all Muslims together ${ }^{10}$

Jihad: armed struggle to defend Islam, whether in a territorial or ideological sense ${ }^{11}$

al-Jihädiyya: tax imposed by the Ottoman Empire used to cover the expenses of jihad, at the beginning temporary, later continued to be permanently taken from local people in all Ottoman provinces and territories ${ }^{12}$

al-Jinn: supernatural creatures

Kalīm (mats): thicker than hașir because they are made of wool and used to cover the walls or the ground to be protected from humidity ${ }^{13}$

1 Majma' al-lugha al-'arabiyya, al-Mu 'jam al-wajizz, wizārat al-tarbiya wa al-ta 'līm, al-Qāhira, 1994, p. 443.

2 al-Wībā, al-Idārā al- '̌uthmānīyyā fì Tarābulis al-ghārb, p. 63.

3 Șabān, al-Mu jam al-mausu'i li-l-mșțalahat al- 'üthmānīyyā al-tārīkhiyya, p. 63.

4 Ibid., p. 45.

5 Hallaq, Wael B.,"Fatwa”, Encyclopedia of the Modern Middle East and North Africa; Encyclopedia.com, McAuliffe, Encyclopaedia of the Quran, pp. 35-42.

6 Nājī, Tārīkh Tarābulis al-ghārb, p. 35.

7 Ibid., p. 51.

8 Majma' al-lugha al-'arabiyya, al-Mu'jam al-wajiz, p. 174.

9 Ibn Mūsā, al-Mujtama' al-'arabì al-lībì, p. 36.

10 Ibid., p.35.

11 McAuliffe, Encyclopaedia of the Quran, pp. 35-42.

12 al-Wībā, al-Idārā al- 'ūthmānīyyā fì Ṭarābulis al-ghārb, p. 160.

13 Ibn Mūsā, al-Mujtama 'al-'arabì al-lībì, pp. 151-152.

DOpen Access. (C) 2021 Suaad Alghafal, published by De Gruyter. (c) BY-NC-ND This work is licensed under the Creative Commons Attribution-NonCommercial-NoDerivatives 4.0 License. 
al-Kuwārighliyya: sons of Ottoman officers of diverse origins who married women from Tripoli ${ }^{14}$ Liwa $\bar{a}^{\prime}$ one of the largest administrative divisions in the Ottoman Empire and its provinces, headed by a mutașarrīf, who was responsible to the governor ${ }^{15}$

Majlis al-baladiyya: municipal Council ${ }^{16}$

Mujāhidīn: persons involved in fighting in jihad ${ }^{17}$

Mutașarrīifiyya: administrative divisions of Ottoman provinces, also called sanjak ${ }^{18}$

Mutațawiūn: persons who were voluntarily enlisted in the conscription or any military actions to defend their country ${ }^{19}$

Nawāhì (sing. nāhiya): smallest administrative divisions of the Ottoman Empire and its provinces, and many of them were under the supervision of $q a d \bar{a}^{3},{ }^{20}$ established in Tripoli after the reforms in 1869 that eliminated the position of Shaykh al-balad, while the Ottomans instead established localities with an elected board of elites of the city or town ${ }^{21}$ Öşür ('ushr): Ottoman tax paid on agricultural products, farmers had to pay one tenth of their agriculture production such as wheat, barley and olives to the government ${ }^{22}$

Pasha: Ottoman title given to honor some governors with military ranks in the Ottoman Empire, also given to the governors of the Ottoman provinces ${ }^{23}$

Qā'im maqām: officer appointed by the Ottoman at the head of any district

Qirsh: silver currency used in the Ottoman Empire ${ }^{24}$

Qunșuliyya (consulate): highest diplomatic representatives of a state in the territories of another state ${ }^{25}$

Raîs al-Baladiyya: head of each municipality (baladiyya) and municipal council who was elected by local municipal notables with active suffrage (censitary suffrage) ${ }^{26}$

Șahrā: Great Desert at the beginning of south Libya, known by the main trade routes linking Tripoli with other trade centers in the south of the Sahara in Africa ${ }^{27}$

Sayyid: Traditional title of descendants of the prophet and a religious position and title given to the leaders of the al-Sanūsiyya movement in Libya ${ }^{28}$

Shaykh al-balad: mayor of the city.

14 Baladiyyat Ṭarābulis fì māà 'at 'àm 1286/1391H, p. 412.

15 al-Wībā, al-Idārā al- 'ūthmānīyyā fī Ṭarābulis al-ghārb, p. 60.

16 Ibid., pp. 73-77.

17 Majma' al-lugha al-'arabiyya, al-Mu 'jam al-wasịț, Dār al-shrūq, al-Qāhira, 2004, p. 124.

18 Masūwd, Jūbran, al-Ra 'ad mu 'jam laghawì a 'ṣrī, Dār al- 'ilim li-l-malāyīn, Bayrūt, 1992, p. 709.

19 Ibid.

20 Kūrū, Lìbiyā athnā̄' al-' 'ahd al-'ūthmānī al-thānī, p. 26; Ibn Mūsā, al-Mujtama 'al- 'arabì al-lībì, p. 19.

21 Ibn Mūsā, al-Mujtama' al-'arabì al-lībī, p. 30.

22 al-Wībā, al-Idārā al- 'ūthmānīyyā fī Ṭarābulis al-ghārb, pp. 135-136.

23 Șabān, al-Mu'jam al-mausu'i li-l-mștalahat, p. 52

24 Ibn Mūsā, al-Mujtama' al- 'arabì al-lībī, pp. 205-205.

25 Majma' al-lugha al-'arabiyya, al-Mu'jam al-wasiț, p. 762.

26 Ibn Mūsā, al-Mujtama' al- 'arabì al-lībī, p. 30.

27 Brūshīn, Tārīkh Lībiyā min nihāyāt al-qarn al-tāsi' 'ashar, p. 43.

28 Morimoto, Kazuo (ed.), Sayyids and Sharifs in Muslim Societies, pp. 2, 11. 
Shaykh al-Islām: It was the highest Islamic position in the Ottoman Empire, also called a mufti with not only a religious role, but also political and legal roles ${ }^{29}$

Shaykh al-mahalla: Head of a tribe, responsible in his area in front of the governor. ${ }^{30}$

Sunna: deeds and sayings of the Islamic prophet Mohammad

Sūq: market ${ }^{31}$

Tanżimāt: political reforms betweeem 1839 and 1876

Tarīqa Șūfiyya: mystical/spiritual schools or orders followed by some Muslims, Sufism emphasize the implementation of the orders of God and to avoid his prohibitions ${ }^{32}$

Waqf (endowment): property withheld from market circulation to be dedicated to philanthropic or religious purposes ${ }^{33}$

Werko: Ottoman annual tax also known as mīri.. ${ }^{34}$

al-Wikāla al-Qunșuliyya (consular agency): diplomatic representation of a lower grade than a consulate, provide help and support to national citizens and strengthen political, economic and cultural relations, sometimes the responsibility of such consular agency was given to a consulate of another state ${ }^{35}$

Wilāyāt (province): ${ }^{36}$ see Eyālet

Wukalä' (sing. wakīl): middleman or broker working for a person or company to represent them in commercial transactions ${ }^{37}$

al-Yahūd: The Jews

29 Ḥalāq, Ḥasan wa 'Abās Șabbāgh, al-Mu jam al-jami' fī al-mușțalāhāât al-ayūbīyya wa almamlūkiyya wa al-'ūthmānīyyā dhāt alușūl al-'arabiyyaa wa al-fārisīyya wa al-turkīyya: almușțalāḥāt al-idārīyyā wa al-'askarīyya wa al-sīyāsiyya wa al-iqtișādīyyā wa al-ijtimā 'ìyya wa al-'ailìyya, Dār al-'ilim li-l-malāyīn, Bayrūt, 1999, p. 133.

30 Kūrū, Lìbiyā athnā' al- 'ahd al- 'ūthmānī al-thānī, p. 27.

31 'Amara, Moḥammad, Mu jam al-mușțalāḥāt al-iqtiṣādīyyā, Dār al-shrūq, al-Qāhira, 1993, p. 299.

32 Majma' al-lugha al-'arabiyya, al-Mu'jam al-wajiz, p. 374.

33 Extracted from http://journal.mufad.org/attachments/article/452/7.pdf, March 2016.

34 al-Wībā, al-Idārā al- 'ūthmānīyyā fī Ṭarābulis al-ghārb, p. 141-142.

35 al-Nașar, 'Abd al-Wahid, al-Mu'assāt al-dawalīyya, Dār ḥațīyn, al-Rabāṭ, 1994, p. 135; Farḥat, Ibn Ṣaf, al-'Ālāqāt al-qunșuliyya, Risālāt mājistīr, Jami 'āt Qsanținna, 2013-2014, p. 88.

36 For this point see Isiksel, Günes, La diplomatie ottomane sous le règne de Selim II.

37 Majma' al-lugha al-'arabiyya, al-Mu'jam al-wajizz, p. 680. 
